\title{
Characteristics of Consumers' Behavior in Shopping of Food Products in the Market of Bosnia and Herzegovina
}

\author{
Beriz Čivić ${ }^{1} \&$ Damir Ćilimković ${ }^{2}$ \\ ${ }^{1}$ Faculty of Economics, University of Tuzla, Tuzla, Bosnia and Herzegovina \\ ${ }^{2}$ Student III Cycle of Studies (Ph.D.) at the Faculty of Economics, University of Tuzla, Tuzla, Bosnia and \\ Herzegovina \\ Correspondence: Beriz Čivić, Faculty of Economics, University of Tuzla, Univerzitetska 8 Street, 75000 Tuzla, \\ Bosnia and Herzegovina. Tel: 387-35-320-820 or 387-61-234-214.
}

Received: October 18, 2017

Accepted: November 7, 2017

Online Published: December 4, 2017

doi:10.5430/rwe.v8n2p49

URL: https://doi.org/10.5430/rwe.v8n2p49

\begin{abstract}
The aim of the study is to systematize factors influencing consumers' decisions relating to the purchase of food products in Bosnia and Herzegovina $(\mathrm{BiH})$, to determine their importance for consumers and establish consumer perception of domestic food products in relation to the imported ones on $\mathrm{BiH}$ market. In the paper, factor analysis was used which showed that the first factor included a group of quality-related features. The second factor includes features related to the brand image, i.e. its market positioning. Although $\mathrm{BiH}$ has a much lower level of living standard than developed countries, the price is not the main criterion when deciding about purchasing food products. In addition, research results show that there is a high level of consumer confidence in domestic food products in BiH.
\end{abstract}

Keywords: consumer behavior, food products, ethnocentrism

JEL classification: M310

\section{Introduction}

The subject of study in many scientific disciplines is an attempt to understand a person as a personality, how he or she responds to certain phenomena, stimuli and changes from the environment. In this context, study of consumer behavior is an important marketing area. Successful marketing management requires knowledge about perceptions, attitudes, preferences, motives, and other elements of consumer behavior in order to understand their decisions in the purchasing process. These insights are one of the key inputs for marketing managers in defining marketing strategies. Based on these inputs, it is possible to create solutions for individual elements of marketing mix that will enable more satisfying consumer needs in a way that is profitable for the company and at the same time better than the competition. This creates prerequisites for achieving long-term consumer affiliation with a given brand or company and its products.

Direct preference implies preference and choice of the given product when making a purchase. From the aspect of the final consumer market, consumer behavior is determined by a number of factors, such as socio-demographic, economic, cultural and many other social factors. However, consumer behavior is affected by the vendors through their marketing activities. This impact, in addition to other marketing activities, is primarily achieved through communication where the bidders (vendors) are seeking to position their brands more successfully with consumers in order to prefer them when making purchasing decisions.

It is important for consumers to build a direct and indirect preference. Direct preference implies preference and choice of a given product when purchasing. The indirect preference is also very important for the company. It means expanding the affirmative image of the given product to the social groups with whom they accomplish communication, thus expanding the circle of potential consumers.

The focus of this paper is on the analysis of consumers' behavior in the food product market in BiH. The characteristics of the final consumer product market in $\mathrm{BiH}$ (in today`s world) are reflected in frequent changes in consumer habits. This, above all, is the result of the globalization trends. 
Nevertheless, there is a parallel presence of strong influence of certain traditional food habits among consumers. In addition, the problem of food safety and origin is increasingly present because of the lack of a reliable state control system in place. The consumer's tendency is to minimize the risk when making purchasing decisions. This is a characteristic of the food market. Consumers collect more and more data from different sources about the supply of nutritional products on the market and analyze them. Their previous experience and information gathered focuses on their behavior in terms of changing buying habits: choice for the same or other brands, the choice of retail outlets where they will be shopping, the level of price, quality, etc. Marketing managers need to gather answers to four fundamental issues related to consumer habits. These are above all: a) what consumers usually buy, b) when they realize this purchase, c) why they need it id) how to make a purchase decision.

The decision-making process related to buying, according to Kotler, begins with the consumer's knowledge of a need that has not been met at all or has not been properly met. The next stage in the process is collecting information. The company should, through communication channels, adequately inform consumers that there is a "solution" to meet their needs. The evaluation of the current bid is the next stage. The consumer, based on the prevailing preferences, attitudes, habits, purchasing motives, evaluates the product's offer and passes to the next phase which is the decision-making about the purchase. The absolute decision whether to make a purchase of a particular product or not is up to the consumer.

And finally, nothing less important in the process of making a purchase decision is a post-buying evaluation. Namely, the buying process does not end with the act of buying. The post-buying phase is something which decides the consumer to re-purchase the same product. If the consumer has met his needs and expectations in the right way, he becomes loyal to a particular product or manufacturer, or vice versa (Kotler \& Keller, 2006).

\section{Literature Review}

The knowledge of features that characterize behavior of consumers is very complex. These features are related to consumer perception, attitudes, and their preference to all elements of the brand (visible and invisible). It should be noted that the differential border of these three features is almost imperceptible. In some elements, they overlap because consumers do not have the ability to create a clear distinction boundary value of the mentioned attributes. For this reason, the holistic concept of observing all the features and aspects affecting consumer behavior should be taken into account.

Among other things, it is important for enterprises (and their market success), to understan consumers in terms of their needs and expectations. They need to realize what consumers like to buy, how they make a purchase, when the shopping is normally implemented, where and why they buy certain products.

Perception describes the way of experiencing certain products. The experience is a subconscious reaction of sensory receptors (mechanism receptors, hearing, balance, hemoreceptors-taste and smell, photoreceptor-sense, thermoreceptor-senses for cold and warm), based on which consumers create a comprehensive picture of a product. Consumer perception can be demonstrated through previous experience gained by future motives and interests to make purchasing decisions. However, perceptions can be influenced by external or external factors that stimulate more intensive purchase of certain products. Attitudes, as part of the characteristics of consumer behavior, represent a complex psychological category in the research process. The complexity of research is derived from the content itself. First of all, they depend on previous knowledge, expectations, beliefs, emotions, feelings, opinions and desires.

Manifestation of the consumer attitude can be caused by the content of communication activities which the company directs towards consumers. Also, a change of attitude may be affected by a narrower or wider environment. For instance, family, friends, colleagues and other groups that an individual trusts or values their opinion (reference group) can affect an attitude. Consumers under the influence of external factors may express a positive or negative attitude (sometimes a neutral attitude) towards a given product.

There is a view that consumers, who prefer high quality products, are not inherent in the constant change, i.e. they do not want to experiment with new and different. Through tendency towards certain products, these consumers become loyal. This is not the case with consumers who prefer only low priced products. Any price change, even small one, usually leads to the purchase of other products of the same category (Anić et al., 2010).

Also, one of the key features in defining consumer behavior is their tendency towards domestic products (the phenomenon of consumer ethnocentrism). The intense manifestation of this phenomenon is the result of the emergence of large socio-economic disparities of the population on a global scale. It can be used through brand management to favor domestic products or stimulate their purchasing. Besides the economic entities (for them this 
goes in favor), this is supported by many governments of the countries in the region, non-governmental organizations, chambers of commerce. The approach is favorited to boost the national economy by increasing domestic purchases, or contributing to economic prosperity. This is confirmed by more frequent communication activities, e.g. "buy domestic". Its primary goal is to influence the awareness of domestic consumers through development of consumer ethnocentrism in order to opt for domestic products during purchasing.

Getting to know the criteria based on which consumers make purchasing decisions is of great importance for long-term growth and development. If marketing managers know the true attributes of products that consumers value positively, and create products accordingly (those that adequately meet their needs, desires and expectations), there is a high likelihood that consumers will be more committed to their products (Milas, 2007). Purchasing is implemented through two phases: pre-buying and post-buying phase. Through the pre-purchase phase, consumers (by impulse reaction and through receptors) receive certain stimulants that opt them for a particular product (packaging, brand name, ads and brand related information). Through combined use of sensory functions they are enabled to estimate the product use, in order to fulfill their primary need (Rodić \& Budimirčević, 2011). However, this does not end the buying process itself. The consumer will decide whether to re-purchase the same product or opt for another one from the same category. If the product purchased completely satisfied the expectations, it is highly probable that the consumer will re-opt for the same product (Schiffman \& Kanuk, 2004). This is why it is important to study the consumers' behavior in the purchasing process as an integral approach. Consumer behavior is one of the key variables of market performance of a company. Internal processes in the enterprise, especially those related to brand development, must be aligned with changes in consumer behavior in order to build long-term consumer preference.

It is important to continually explore consumer behaviors, as they are subjected to the many influences from the environment. Namely, the study of consumer innovativeness unveils consumers' behavioral tendencies in the diffusion process of a new product or services in society. With the emergence of global online markets, the concept of globalization has become a crucial factor in the introduction of new products and services of multinational companies. However, it is also important to note that the degree of diffusion rate differs across the countries, resulting in the divergence of consumer innovativeness (Kim et al., 2017).

Modern technologies have a significant impact on changes in consumer habits. The results of research conducted by Arora, Singha and Sahney show that "touching and feeling the product" and "sales staff assistance" motivated customers to visit the physical store before buying online. "Better Online Service Quality" and "Lower Prices Online" induced customers to later purchase online. Price conscious customers and those with the ability to use multiple channels were more likely to engage in showrooming behavior (Arora et al., 2017). Despite the growing popularity of consumers adopting $\mathrm{m}$-shopping activities and the increasing academic attention, consumer $\mathrm{m}$-shopping utilization remains low and research of its causes remains in its infancy (Marriott et al., 2017).

For a better understanding of current consumer habits, marketing managers need to explore the evolution of consumer behavior in a particular market segment. Namely, an understanding of evolutionary needs can provide insight into consumer preferences and decision processes. For example, some people happily spend their hard-earned money on ultra-expensive luxury goods with no survival benefits. People also make seemingly irrational choices by seeking to avoid losses instead of gaining gains. An evolutionary perspective provides a powerful new framework with a host of implications for theory and research in consumer behavior (Griskevicius \& Kenrick, 2013).

Considering the fact that $\mathrm{BiH}$ belongs to the group of the least developed countries in Europe and that there are no serious studies in $\mathrm{BiH}$ about the consumers' behavior in the market of food products, the motive for this research is to explore what determines consumers about decisions in the purchasing process in the food market in $\mathrm{BiH}$. In other words, the author's motive is to investigate whether price is the primary factor for consumers in the market of food products because $\mathrm{BiH}$ is in the group of countries with the lowest GDP per capita in Europe, and which are other factors that determine consumers' purchasing decisions. In addition, $\mathrm{BiH}$ is a liberalized market in which a large number of foreign food suppliers are present. In view of this, the intention of this research is to determine how much it is represented consumer ethnocentrism in the market of food products in $\mathrm{BiH}$.

\section{Research Methodology}

The aims of the research: 1) Analysis of factors influencing consumers' decisions on purchasing food products in $\mathrm{BiH}, 2$ ) Establishing the ranking criteria for consumers in buying food products in $\mathrm{BiH}$ and 3) Determining consumer perceptions of domestic food products on $\mathrm{BiH}$ market. 


\section{Research hypotheses:}

Hypothesis 1. Although $\mathrm{BiH}$ has a lower level of living standard in relation to developed countries (given the average net wage and GDP per capita), the price is not the main criterion when deciding on purchasing food products on $\mathrm{BiH}$ market.

Hypothesis 2. In $\mathrm{BiH}$ there is consumer confidence in domestic food products.

Data collection: The data presented in the following part of the paper are the result of the primary research. The data are collected by means of a survey (written structural survey). The questionnaire was filled by buyers aged 18 years old at shopping malls in larger cities in $\mathrm{BiH}$. The sample size is 150 examinees. The data collection was conducted in May 2017.

\section{Result Analysis and Discussion}

We will present the aims of the empirical research about the features of consumer behavior on foodproduct market in $\mathrm{BiH}$.

\subsection{Factors Affecting Consumer Decisions about the Purchase of Food Products in BiH}

Consumer spending decisions are influenced by a large number of factors. This is especially true when buying food products. In addition to the usual factors (quality and price), when purchasing food products, there are particularly important factors related to the trust in individual brands, the experiences of other consumers and certain habits that are based on the tradition of a certain environment. Within this research, we observed a number of factors which determine consumer decisions while purchasing food products on the BiH market.

Some of these features are mutually similar. The observation of similar features had a control role in order to monitor the consistency of responses. The importance of each factor was assessed by the respondents on a scale from 1 to 5.1 is the least important (the respondent does not recognize himself in the statement) and 5 is the most important (the respondent fully recognizes himself in this statement).

Because of the greater number of features, factor analysis was applied to group them into a smaller number of factors and to determine the influence of individual factors on the variation of the observed appearance. Table 1 shows the values of Bartlett's test of sphericity and Kaiser-Meyer-Oklin Measure of Sampling Adequacy. These two tests are needed to evaluate the feasibility of applying factor analysis.

Table 1. KMO and Bartlett's Test

\begin{tabular}{llr}
\hline & Kaiser-Meyer-Olkin Measure of Sampling Adequacy & 0,678 \\
\hline Bartlett's Test of Sphericity & Approx. Chi-Square & 1883,893 \\
& Df & 630 \\
& Sig. & 0,000 \\
\hline
\end{tabular}

Source: Author's research.

Given that the value of KMO indicator is in the range 0.5-1.0 (KMO = 0.678), in the specific case there is a benefit and justification to apply factor analysis. According to the results of Bartlett's test $(\mathrm{Sig} .=0,000)$ there is a significant correlation between observed original variables.

As the method of separating the factors, the main component procedure was applied in the analysis. For criterion of selecting the number of factors we chose, critical values associated with factors greater than 1 . According to the data given in Table 2, the first ten factors have critical values greater than 1 and these ten factors explain $62.69 \%$ of variance. 
Table 2. Total variance explained

\begin{tabular}{|c|c|c|c|c|c|c|c|c|c|}
\hline \multirow[b]{2}{*}{ Component } & \multicolumn{3}{|c|}{ Initial Eigenvalues } & \multicolumn{3}{|c|}{$\begin{array}{c}\text { Extraction Sums of Squared } \\
\text { Loadings }\end{array}$} & \multicolumn{3}{|c|}{$\begin{array}{c}\text { Rotation Sums of Squared } \\
\text { Loadings }\end{array}$} \\
\hline & Total & $\begin{array}{c}\% \text { of } \\
\text { Variance }\end{array}$ & $\begin{array}{c}\text { Cumulativ } \\
\text { e } \%\end{array}$ & Total & $\begin{array}{c}\% \text { of } \\
\text { Variance }\end{array}$ & $\begin{array}{c}\text { Cumulative } \\
\%\end{array}$ & Total & $\begin{array}{c}\% \text { of } \\
\text { Variance }\end{array}$ & $\begin{array}{c}\text { Cumulativ } \\
\text { e } \%\end{array}$ \\
\hline 1 & 5,435 & 15,098 & 15,098 & 5,435 & 15,098 & 15,098 & 4,075 & 11,320 & 11,320 \\
\hline 2 & 3,203 & 8,897 & 23,995 & 3,203 & 8,897 & 23,995 & 3,253 & 9,036 & 20,357 \\
\hline 3 & 2,897 & 8,046 & 32,042 & 2,897 & 8,046 & 32,042 & 2,817 & 7,824 & 28,181 \\
\hline 4 & 2,558 & 7,105 & 39,146 & 2,558 & 7,105 & 39,146 & 2,774 & 7,707 & 35,888 \\
\hline 5 & 2,003 & 5,565 & 44,712 & 2,003 & 5,565 & 44,712 & 2,316 & 6,433 & 42,321 \\
\hline 6 & 1,609 & 4,469 & 49,180 & 1,609 & 4,469 & 49,180 & 1,731 & 4,807 & 47,128 \\
\hline 7 & 1,407 & 3,908 & 53,088 & 1,407 & 3,908 & 53,088 & 1,514 & 4,205 & 51,334 \\
\hline 8 & 1,266 & 3,518 & 56,606 & 1,266 & 3,518 & 56,606 & 1,442 & 4,007 & 55,340 \\
\hline 9 & 1,111 & 3,086 & 59,692 & 1,111 & 3,086 & 59,692 & 1,385 & 3,848 & 59,188 \\
\hline 10 & 1,082 & 3,006 & 62,699 & 1,082 & 3,006 & 62,699 & 1,264 & 3,511 & 62,699 \\
\hline 11 & ,957 & 2,659 & 65,357 & & & & & & \\
\hline 12 & ,939 & 2,608 & 67,965 & & & & & & \\
\hline 13 & ,908 & 2,522 & 70,487 & & & & & & \\
\hline 14 & ,869 & 2,414 & 72,901 & & & & & & \\
\hline 15 & ,809 & 2,246 & 75,148 & & & & & & \\
\hline 16 & ,770 & 2,140 & 77,288 & & & & & & \\
\hline 17 &, 719 & 1,999 & 79,286 & & & & & & \\
\hline 18 & ,686 & 1,905 & 81,192 & & & & & & \\
\hline 19 &, 655 & 1,820 & 83,011 & & & & & & \\
\hline 20 &, 635 & 1,763 & 84,774 & & & & & & \\
\hline 21 &, 560 & 1,557 & 86,331 & & & & & & \\
\hline 22 &, 511 & 1,419 & 87,750 & & & & & & \\
\hline 23 & ,491 & 1,365 & 89,115 & & & & & & \\
\hline 24 &, 478 & 1,327 & 90,442 & & & & & & \\
\hline 25 & ,432 & 1,201 & 91,643 & & & & & & \\
\hline 26 & ,397 & 1,103 & 92,746 & & & & & & \\
\hline 27 & ,368 & 1,023 & 93,769 & & & & & & \\
\hline 28 & ,360 & 1,001 & 94,770 & & & & & & \\
\hline 29 &, 333 & ,925 & 95,695 & & & & & & \\
\hline 30 & ,300 &, 834 & 96,528 & & & & & & \\
\hline 31 &, 270 &, 750 & 97,278 & & & & & & \\
\hline 32 &, 251 & ,697 & 97,975 & & & & & & \\
\hline 33 &, 223 &, 618 & 98,593 & & & & & & \\
\hline 34 & ,190 &, 528 & 99,121 & & & & & & \\
\hline 35 &, 160 &, 444 & 99,565 & & & & & & \\
\hline 36 &, 157 &, 435 & 100,000 & & & & & & \\
\hline
\end{tabular}

Extraction Method: Principal Component Analysis.

Source: Author's research 
The results presented in Table 3 show the following:

1. The first factor is related to quality and is made of the following features:

- consumers' readiness to invest heavily in purchase to choose the best quality product [weighting coefficient 0,809 or $65,4 \%(0,809 \times 0,809=0,654)]$,

- in view of this, consumers, in principle, always strive to buy high quality products [weighting coefficients 0.795 and $63.2 \%(0.795 \times 0.795=0.632)]$, etc.;

2. The second factor is related to brand image, i.e. its market positioning and is made of the following features:

- Consumers' belief that luxury stores offer the best products [weighing coefficients 0.763 and $58.2 \%$ $(0.763 \times 0.763=0.582)]$,

- Consumers` belief that higher product prices mean higher product quality [weighting coefficient 0.696 or $48.4 \%(0.696 \times 0.696=0.484)]$, etc.;

3. Within the third factor, it is interesting to note that the attitude of a friend has a significant influence on consumer purchasing decisions in the food products market [weighting coefficient 0.640 and 40.9\% $(0.640 \times 0.640=0.409)$ ]

A more detailed factor content with weight coefficients of individual characteristics is presented in Table 3.

Table 3. Rotated component matrix

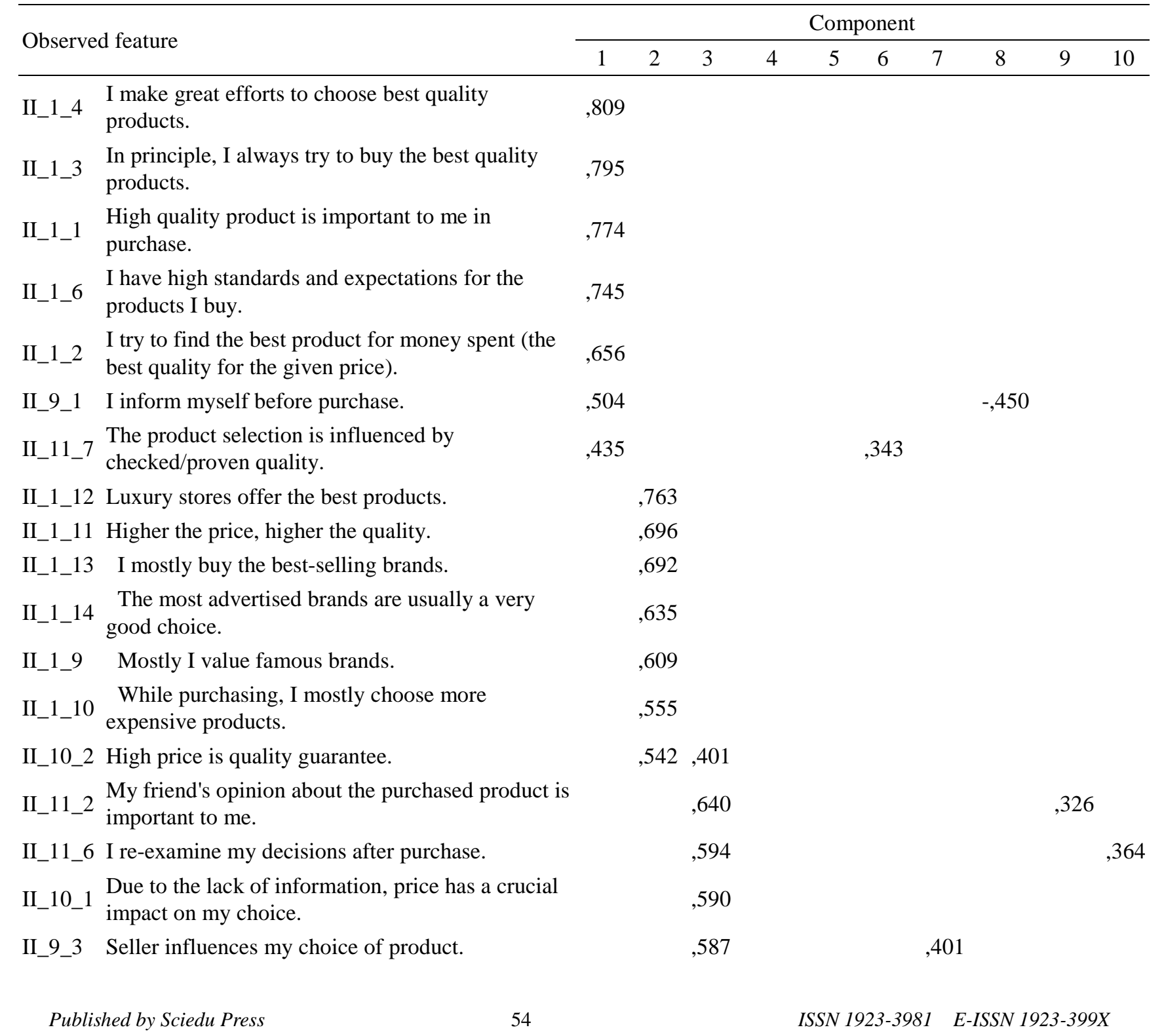


Observed feature $\quad$ Component

\begin{tabular}{lllllllllll}
\hline 1 & 2 & 3 & 4 & 5 & 6 & 7 & 8 & 9 & 10
\end{tabular}

II_11_5 $\begin{aligned} & \text { I listen to experience of others before purchase } \\ & \text { decision. }\end{aligned}$ , 575

II_10_4 I consider retail store image a quality guarantee.

II_11_1 I like to experiment in purchase and buy new

II_1_19 Once I find the product I like, I stick to it. II_1_18 I have favourite brands which I constantly

II_1_20 I always go to same shops when I purchase.

II_10_3 I buy the same brand.

II_1_15 As much as possible I try to buy on discounts, i.e. at reduced prices.

II_1_16 Cheaper products are mostly my shopping choice. II_9_2 $\begin{aligned} & \text { Discounts and promotions affect my product } \\ & \text { choice. }\end{aligned}$

II_1_17 I try to find the best value for money.

II_11_4 When shopping, I check the correctness of the product, shelf life and other data. II_11_3 If I'm not happy with a product, I advertise it to the

II_1_7 I bu the first product I find that meets my requirements.

II_1_5 I do not ponder a lot nor invest too much effort during shopping.

II_9_4 I dislike unknown shopping situations.

II_1_21 I regularly change brands which I purchase.

II_1_8 Product does not have to be perfect or the best to

Extraction Method: Principal Component Analysis.

Rotation Method: Varimax with Kaiser Normalization.

a. Rotation converged in 10 iterations.

Source: Author's research

\subsection{A Ranking of Consumer-driven Criteria for Purchasing Food Products in BiH}

One of the aims of the research was to establish the rank of criteria of importance for consumers when purchasing food products in the $\mathrm{BiH}$ market. It isexpected that quality and price are to be found at the first and second place as the most important factors to account for when purchasing food products. However, for all serious companies, quality and price are used as a basis for building competitive advantage. The management of manufacturing companies considers ranking of other factors on the basis of which consumers make their purchasing decisions on food products as very important. These factors can be a significant source of competitive advantage and the basis the consumers' preference. 


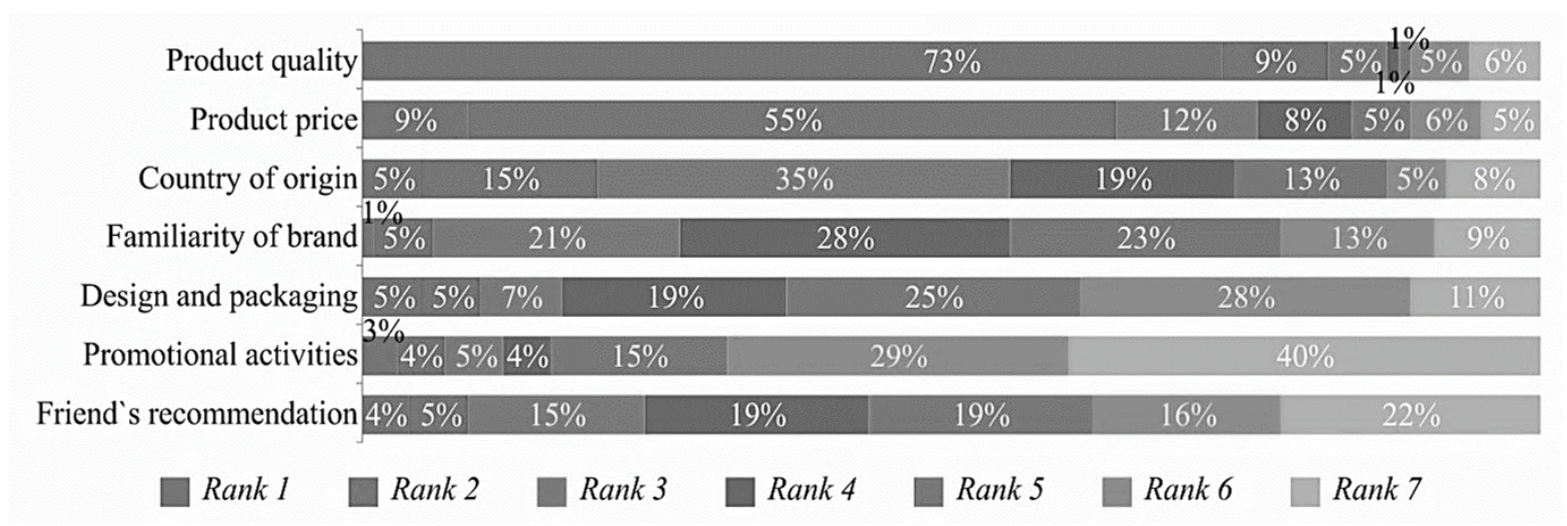

Figure 1. Ranking criteria of importance for respondents in purchase of food products in BiH (Author's research)

As expected, the largest number of respondents (73\%) ranked quality as the first in importance when purchasing, and 9\% ranked it in the second place. Price has the second importance with most respondents (56\%). With $9 \%$ of respondents, price is ranked the first when buying food products in $\mathrm{BiH}$ market. With $1 / 3$ of the respondents, the country of origin is the third in importance. With $1 / 5$ of respondents it is brand 's familiarity, and in $15 \%$ of respondents it is a friend's recommendation.

The same criteria (brand familiarity, country of origin and friend's recommendation) are the fourth criterion of importance with $28 \%$ and $19 \%$ of respondents respectively (Figure 1). Promotional activities have the least importance (seventh criterion in $40 \%$ of respondents and sixth criterion in $29 \%$ of respondents) when deciding to purchase food products in $\mathrm{BiH}$

\subsection{Consumer Perception about Domestic Products in the Food Product Market in BiH}

For the large number of consumers, the country of origin is the third criterion to guide the decision-making about purchasing food products. This is why the study sought to explain in more detail the perception of consumers about domestic food products. Generally, BiH consumers have a very positive attitude towards domestic food products. More than 2/3 of respondents have more confidence in domestic food brands compared to imported ones (Figure 2).

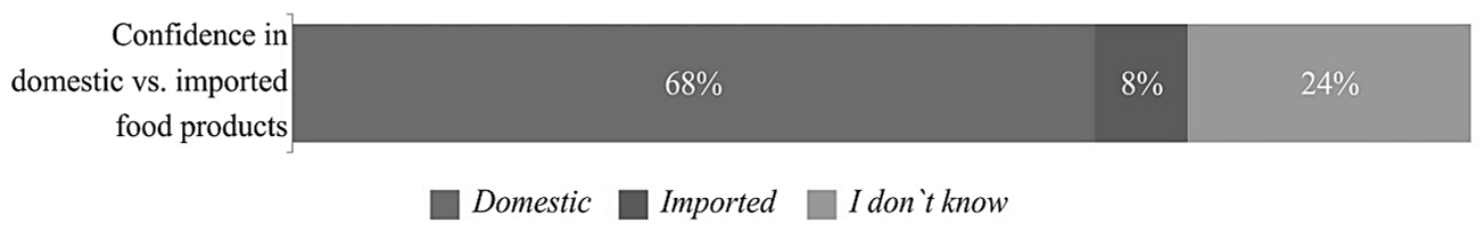

Figure 2. Confidence in domestic vs. imported food products in BiH (Author's research)

A significant proportion of respondents (around 1/4) do not have a clear attitude about this issue. The very fact that it is a "domestic" product can not be the basic criterion for its market positioning. It is important that domestic products are competitive according to the basic criteria for consumer purchasing decisions, namely quality and price. Figure 3 shows the characteristics of the respondents who have more confidence in domestic than the imported food products. 


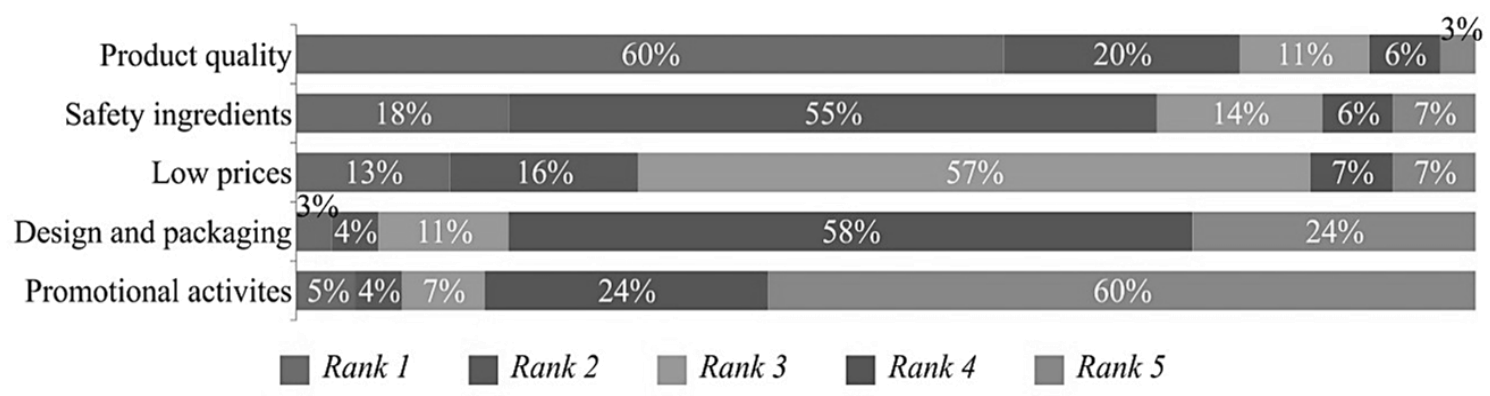

Figure 3. Ranking of features according to which consumers give preference to domestic products compared to imported ones (Author's research)

For the highest number of respondents (61\%), the first criterion for preference to domestic food products compared to imported ones is quality. The safety of products with regard to the ingredients, is the second most important criterion for the largest number of respondents (56\%). Lower domestic product prices are for $57 \%$ of the respondents in the third place. For $58 \%$ of the respondents in the fourth place of importance are design and packaging.

\section{Conclusion}

Summary of findings: Consumers are the chief judge for the market success of the company. Researching features that characterize consumer behavior is of utmost importance to marketing managers. They are able to develop marketing solutions that will serve to build long-term relationships with consumers and create their loyalty to the company and its products. Consumer behavior is characterized by a large number of factors and they are specific to particular market segments.

Marketing managers should identify key features that reflect consumer habits in their market segment. This can be achieved by research, first and foremost, of the criteria on the basis of which consumers make their purchasing decisions, which make them decide for a given product. Additionally, it is important to determine the impact of individual factors which influence consumer decisions. Based on these findings, marketing managers can create a competitive offer that will be geared to meeting demand in aspects that are particularly important to consumers.

The research results confirm the first hypothesis that price is not the leading criterion when deciding to buy food products in the $\mathrm{BiH}$ market. Regardless of the lower living standard in $\mathrm{BiH}$ compared to developed countries, for the vast majority of respondents (73\%) the first criterion of importance in deciding to buy food products is quality. Only $9 \%$ of the respondents have stated the price as the first criterion for purchase decision. The price, for half of the respondents (56\%) is another criterion when deciding on purchasing food products. In addition to quality and price, the next criteria of importance are the country of product origin, brand reputation and friends` reference.

Data obtained through this research show that there is a high level of consumer confidence in domestic food products, which confirms the second hypothesis. According to research results, $68 \%$ of respondents have more confidence in domestic than imported food products, while only $8 \%$ of respondents stated they had more confidence in imported food products. The first reason for this is that respondents believe that domestic food products are better than imported. That's what $61 \%$ of respondents think. As a second reason for higher domestic confidence is that respondents believe that the ingredients from which domestic food products are made are safer than the ingredients used in imported food products.

Managerial implications/management knowledge: The results of this research are relevant for marketing managers in the food industry. Primarily, the research results show a clear preference for domestic food products compared to consumer imports, which is a significant input to market creation. But consumers do not easily trust the domestic food industry either. They expect domestic food products to be of high quality and composed of safe ingredients. Marketing managers must always have this expectation of consumers in their minds. Secondly, research results show that marketing managers in the food industry can not expect premium prices or premium margins. Consumers are willing to opt for quality first. However, quality as a second criterion significantly influences consumers' decisions when purchasing food products in the BiH market.

Research limitations: The conducted research contains limitations, which are, inter alia, reflected in a relatively small sample of examinees and a more detailed analysis of the determinants of decision making by individual groups 
towards the food products and to individual socio-demographic segments of the respondents. Namely, for more in-depth study of the characteristics of consumer behavior in the food market, it is necessary to include a larger number of respondents in the research. In addition, it is necessary to analyze in detail the influence of certain factors on the decision-making of consumers in the purchase of certain categories of food products. It would also be helpful to analyze the existence of differences in terms of deciding on the purchase of food products between different socio-demographic groups of consumers.

Recommendation for further research: It would be useful to analyze changes in consumer habits in the food markets of countries in the region, or countries with similar traditional eating habits, in the future research. The next important issue which, among other things, deserves to be the subject of future research is the analysis of the impact of changes in the lifestyle which occurs in contemporary society with consumers` nutrition habits.

\section{References}

Anić, I. D., Piri, R. S., \& Rajh, E. (2010). Uticaj kvalitete i cijene na lojalnost marki. Ekonomski pregled, 61, 137-150.

Arora, S., Singha, K., \& Sahney, S. (2017). Understanding consumer's showrooming behaviour: Extending the theory of planned behaviour. Asia Pacific Journal of Marketing And Logistics, 29(2), 409-431. https://doi.org/10.1108/APJML-06-2016-0111

Griskevicius, V., \& Kenrick, D. T. (2013). Fundamental motives: How evolutionary needs influence consumer behavior. Journal of Consumer Psychology, 23(3), 372-386. https://doi.org/10.1016/j.jcps.2013.03.003

Kim, W., Di Benedetto, C. A., \& Hunt, J. M. (2017). Consumer innovativeness and international consumer behavior: Comments and extensions. Journal of Global Scholars of Marketing Science, 27(3), 184-194. https://doi.org/10.1080/21639159.2017.1318668

Kotler, P., \& Keller, K. L. (2006). Marketing menadžment. Beograd: Data status.

Marriott, H. R., Williams, M. D., \& Dwivedi, Y. K. (2017). What do we know about consumer m-shopping behaviour?. International Journal of Retail \& Distribution Management, 45(6), 568-586. https://doi.org/10.1108/IJRDM-09-2016-0164

Milas, G. (2007). Psihologija marketinga. Zagreb: Target.

Rodić, J., \& Budimirčević, K. (2011). Marketing istraživanje percepcije potrošača. Marketing SeMA, 42(2), 127-134.

Schiffman, L. G., \& Kanuk, L. L. (2004). Ponašanje potrošača. Zagreb: Mate. 